\title{
"SUURIN HUOLENAIHE NYKYTILANTEESSA ON TOTUUS"
}

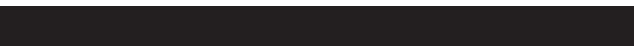

Sari Kivistö \& Sami Pihlström: Sivistyksen puolustus, Gaudeamus 2018.

On outoa, kuinka länsimaisen sivistysihanteen perustermit, 'vapaus' ja 'totuus', ovat hävinneet jopa akateemisesta keskustelusta. Vaikuttaa hämmästyttävältä, että tutkimuksen ja opetuksen keskeisiä ideaaleja tuhansia vuosia jäsentäneet käsitteet haihtuvat muutamassa vuosikymmenessä ilmaan aivan kuin niillä ei alun perinkään olisi ollut merkitystä. Nyt on kuitenkin ilmestynyt teos, jossa totuus ja vapaus ovat ahkerassa käytössä. Sivistyksen puolustuksessa Sari Kivistön ja Sami Pihlströmin puolustus rakentuu näille perinteisille käsitteille, jotka nostetaan tarkastelun keskiöön.

Kivistö ja Pihlström esittelevät teoksen teemaa seuraavasti: "Kirjamme vastaa kysymykseen, 'mitä on akateeminen elämä, ja pyrkii kertomaan, miksi se on nyky-yhteiskunnassa olennaisen tärkeää" (7). Vapauden ja totuuden teemojen ohella teos pohtii siis näiden arvojen mukaista elämää, jollaisena kirjoittajat pitävät nimenomaan akateemista elämää. Kivistölle ja Pihlströmille sivistyksen puolustaminen tarkoittaa ennen kaikkea sellaisen elämän puolustamista, "johon akateemiseen työhön asettuneet ihmiset ovat sitoutuneet ja jonka elämisen he kokevat tärkeäksi” (10). He puolustavat akateemista elämää erityisesti humanistisella alalla, jonka he näkevät olevan nykyisen yliopistopolitiikan vuoksi vakavimmin uhattuna.

Kivistö ja Pihlström ymmärtävät hyvin olevansa konservatiivisia esittäessään, että vanhoja akateemisia arvoja ei pitäisi unohtaa uutuuksien kasvavassa paineessa. He ilmoittavat olevansa vahvasti sitoutuneita humboldtilaisen sivistysyliopiston arvoperustaan (215). Tämä arvoperusta on usein liitetty ajatukseen yliopiston ideasta, eli näkemykseen, että korkeimpien oppilaitosten tulisi toteuttaa totuuden ja vapauden ideaalia sen sijaan, että ne toteuttaisivat yhteiskunnan asettamia tehtäviä, kuten koulutustarpeeseen vastaaminen ja innovaatioiden kehittäminen talouskasvun tarpeisiin. Vanhassa mallissa akateeminen maailma näyttää suuntaa yhteiskunnalle, kun taas uudemmissa näkemyksissä yliopistoyhteisön tehtävä on suorittaa sille määrätyt tehtävät. Yliopistossa työskentelevien kannalta tämä on usein johtanut "vieraantumiseen akateemisen elämän subjektin roolista" (102).

Kirjan keskeinen huoli muotoutuu seuraavaksi kysymykseksi: "[O]nko yliopistossa tilaa tutkijoille, joiden työtä ohjaa ensisijaisesti totuuden tavoittelu tai näkemyksellisen tutkimustiedon kehittely, vaikka se ei suoraan vastaisi markkinoiden oletettuihin välittömiin tarpeisiin” (58). Voimme ajatella, että keskiajalla totuuden mittapuuna oli kristinusko ja tämä asetelma rajoitti akateemista vapautta. Vapauden rajoittajana uskonnon on korvannut raha: nykyään ajatellaan usein, että "[t]ieto on turhaa, jos se ei tuota rahaa" (206). Kivistö ja Pihlström ovat siis huolissaan siitä, onko akateeminen vapaus ajautunut niin ahtaalle, että totuutta sen itsensä vuoksi tavoitteleva tutkija ei enää löydä paikkaa yliopistoyhteisöstä.

Kivistön ja Pihlströmin näkemyksessä kysymyksellä ajasta on keskeinen rooli. Humanistisen alan tutkimuksen onnistumista tulisi tarkastella pitkällä aikavälillä (11), kun taas 
nykyiset mallit korostavat nopeasti näkyviä tuloksia. Länsimainen yliopistomalli on ollut maailmanhistoriallinen menestystarina, mutta monet sen keskeiset saavutukset ovat tulleet nähtäviksi vasta ajan kuluessa. On helppo yhtyä kirjoittajien huoleen siitä, tietävätkö yliopistojen muutoksista vastaavat tahot todella, mitä he ovat tekemässä. (Kirjoittajat viittaavat myös Jussi Valtosen romaaniin He eivät tiedä mitä tekevät.) Kivistö ja Pihlström muotoilevat akateemiseen vapauteen puuttumisen seuraavasti: "Tiedeyhteisö on pahassa pulassa, kun herää pieninkin epäilys siitä, ettei akateeminen vapaus ole toimintaa ohjaava perusarvo" (147). Tällainen "pieni epäilys" on jo herännyt monellakin taholla, mutta ei näytä, että asiaa tiedostettaisiin pahaksi pulaksi.

Kirjoittajat puolustavat perinteisiä akateemisia toimintamalleja, kuten monografioiden kirjoittamista ja jopa yksin työskentelyä. Sivistyksen ja totuuden kannalta on tärkeää kirjoittaa yksin perusteellisia monografioita: "monografia on arvokkaampi kuin koskaan juuri siksi, että sen muoto kulkee käsi kädessä syvällisen pyrkimyksen kanssa” (87). Yksinäistä työskentelyä kirjoittajat puolustavat seuraavasti: "Yksin tekeminen, hiljainen tutkimus ja pitkäjänteinen keskittyminen ovat epämuodikkuudestaan huolimatta olennainen osa vakavasti otettavaa tieteellistä tieteen tekemistä" (109). Laajan monografian kirjoittaminen yksin varmasti antaa kriittistä etäisyyttä asioihin, mutta toisaalta myös tällöin työskennellään tutkijayhteisössä. Teos avaa oleellisen näkökulman tiedeyhteisöjen muokkaantuviin toimintatapoihin puolustaessaan perinteistä toimintamallia, mutta jokin havainnollistus olisi ollut kohdallaan niille, joilla ei ole kokemusta siitä, kuinka totuus tavoitetaan nimenomaan monografialla.

Kirjoittajat eivät selvästikään tervehdi ilolla konsulttikulttuurin viimeaikaista rantautu- mista akateemiseen maailmaan. Onkin outoa, kuinka erinäisiä uudistuksia toteutetaan konsulttivetoisesti, vaikka yliopistolla itsellään on alalta erinomaista asiantuntemusta. Tästäkin teemasta kirjoittajat olisivat voineet nostaa esiin muutaman havainnollistuksen vaikkapa johtamismalleista.

Taustaltaan humanistinen lukija ottaa akateemisen vapauden ja totuuden puolustamisen ilolla vastaan, mutta kuten hyvään keskustelunavaukseen kuuluukin, ilmaan jää kysymyksiä. Olisiko kuitenkin mahdollista pitää kiinni vanhoista arvoista ja uudistaa tapaamme toimia internetin aikakaudella? Esimerkiksi Rupert Wegerif tekee nykytilanteesta johtopäätöksen, että kirjallisen kulttuurin kukoistus on ohi. Siksi meidän tulisi miettiä keinoja pitää kiinni keskeisistä eettisistä arvoista internetin aikakaudella. Nykyään on myös alkanut kuulua puheenvuoroja, joiden mukaan tutkimuksen sijaan akateemisen yhteisön keskeisistä arvoista voitaisiin pitää kiinni opetuksen alueella (esim. Jon Nixon). Kivistön ja Pihlströmin kirjassa opetus jää vähälle huomiolle, mutta olisi kohtuutonta olettaa lyhyeltä teokselta kaikenkattavuutta. Kirjoittajille ei myöskään tunnu tulevan mieleen joissakin julkaisuissa jo esiin nostettu mahdollisuus, että yliopistojen aika totuuden ja vapauden tyyssijana alkaa olla ohi ja niiden vaalimisen tehtävää hoitamaan pitäisi kehittää uusia yhteisöjä.

Vaikka kirjoittajat myöntävät olevansa konservatiivisia, he eivät sinällään - Snellmanin hengessä - ole uudistuksia vastaan, ja on kirjalle ansioksi, että se saa pohtimaan uudistusten mielekkyyttä ja mahdollisuuksia. Ainakin teos herättää huolen siitä, että jos uudistettu akateeminen kulttuuri ei enää toimi pitkällä aikajänteellä vanhaan tapaan tuottaen odottamattomia onnistumisia, taitaa jo olla myöhäistä kääntyä takaisin.

\section{— JUHA HIMANKA}

